Research Article

\title{
A descriptive study to assess factors affecting core indicators of infant and young child feeding practices in urban area of Gujarat State, India
}

\author{
Bhavik M. Rana*, Haresh Chandwani, K. N. Sonaliya, Arpit Prajapati
}

Department of Community Medicine, GCS Medical College, Opposite DRM Office, Ahmedabad-380025, Gujarat, India

Received: 21Feburary 2016

Accepted: 17 March 2016

*Correspondence:

Dr. Bhavik M. Rana,

E-mail: dr.bhavikrana@hotmail.com

Copyright: () the author(s), publisher and licensee Medip Academy. This is an open-access article distributed under the terms of the Creative Commons Attribution Non-Commercial License, which permits unrestricted non-commercial use, distribution, and reproduction in any medium, provided the original work is properly cited.

\begin{abstract}
Background: Infant and young child feeding (IYCF) practices followed by mother during first 2 years of her child directly affect the health status of the child in the long run. To reduce the infant and under five mortality rate it is imperative that mothers practice appropriate IYCF practices as guided by World Health Organization. The main objective of the study was to assess the factors affecting IYCF practices among sampled population.

Methodology: Current cross sectional study was conducted with sample comprising 300 mothers having children aged 0-23 months. Early initiation of breastfeeding, Pre lacteal feeding, exclusive breastfeeding and predominant breastfeeding practices followed by mothers, were analyzed in the current study.

Results: Around $88 \%$ children were started early breast feeding. The number of mothers who gave pre-lacteal feed to their new born was $11(2.75 \%)$. 281(66\%) mothers out of the sampled population were giving exclusive breast feeding. Only 12 (3\%) study population was providing predominant breast feeding. The socio-demographic characteristics like education of mother, maturity of nursing mother, socio economic class of mother and antenatal care received by mother were found significantly affecting these practices.

Conclusion: The indicators for the exclusive breast feeding practices are not at the desired level. There is need to improve the knowledge of mothers regarding IYCF practices.
\end{abstract}

Key words: Nutrition, IYCF, Under five mortality rate

\section{INTRODUCTION}

There has been consistent decline in infant mortality rate (IMR) and under five mortality rate over last few decades. ${ }^{1}$ However in comparison to developed countries, India still has a long way to go in terms of improvements in above mentioned mortality indicators.

The Infant Mortality Rate (IMR) has registered 2 points decline to 40 in 2013 from 42 in 2012 at the National level. $^{2}$ The IMR of rural areas in India still remains higher (44 per 1000 Live Births) than national average. In
2013, under five mortality rate for the country has shown a decline of 3 points over 2012 (49 in 2013 against 52 in 2012). The scientific evidences have shown that malnutrition is responsible for nearly $60 \%$ of all deaths amongst children less than five years of age. ${ }^{3}$

Protein Energy Malnutrition (PEM) is still one of the leading contributors in childhood mortality. World's top five causes of under-five mortality include pneumonia, diarrhoea and malaria. 
These diseases are more likely to be fatal amongst those children whose immune system is already weakened by malnutrition. ${ }^{1}$ About $67 \%$ of the child deaths in India are due to the perpetuating effects of malnutrition. ${ }^{4}$ Correct diet is essential in growth and development of children, particularly in the first two years of life. ${ }^{5}$

World Health Organization (WHO) recommends exclusive breast-feeding (BF) for the first six month of age; addition of complementary feeds at six months with continued BF till two years to reduce the burden of malnutrition, correct Infant and Young Child Feeding (IYCF) plays a major.

Upon identification of the need, WHO and UNICE have developed IYCF techniques which are applicable to all the countries and have the potential to reduce the prevalence of malnutrition if followed correctly.

Many factors have been found out affecting feeding practices.

It has been said that infants aged 0-5 months who are not breastfed have seven-fold and five-fold increased risks of death from diarrhoea and pneumonia, respectively, compared to exclusively breastfed infants. ${ }^{4}$

Education of mother, socioeconomic class of family, social customs like avoidance of colostrum's etc. affect the feeding practices directly or indirectly. Current study has focused on some of the core indicators of IYCF practices to reflect upon the prevailing feeding in the urban area of Gujarat state.

The main objective of the study was to assess the factors affecting IYCF practices among sampled population.

\section{METHODS}

Current cross sectional study was conducted at field practice areas of urban health training center of GCS Medical College, Ahmedabad from November 2013 to April 2014 following ethical clearance from institutional ethics committee.

Study sample comprised of mothers having children aged 0-23 months. A total of 300 eligible mothers were approached through house to house visit to participate in the study by convenient sampling method.

Informed consent was obtained from the mothers before data collection. The data were collected by interview method using a pre-tested performa.

Data were analyzed through Epi-info software. Following definitions were used to assess Infant and Young Child Feeding (IYCF) practices in the present study.
Initiation of breast feeding should be started within first hour of birth. Pre lacteal feeding is any food other than breast milk given to the new-born after birth before initiating breast feeding.

Exclusive breastfeeding is no other food or drink, not even water, except breast milk (including milk expressed or from a wet nurse) for 6 months of life, but allows the infant to receive ORS, drops and syrups (vitamins, minerals and medicines).

Predominant breastfeeding: The infant's predominant source of nourishment has been breast milk (including milk expressed or from a wet nurse as the predominant source of nourishment). However, the infant may also have received liquids (water and water-based drinks, fruit juice) ritual fluids and ORS, drops or syrups (vitamins, minerals and medicines).

\section{RESULTS}

Current study involved 300 mothers with their children aged less than 24 months of age. As per table 1, the feeding habits about $55.7 \%$ male and $44.3 \%$ female children were obtained from their mothers. Majority of participating mothers were from age group of 26 to 30 years $(49.7 \%)$.

Only $0.3 \%$ study participants were less than 20 years of age. It was found that $14.3 \%$ mothers were illiterate. Very few $(1.7 \%)$ mothers were having qualifications of graduation or above.

Almost half of study participants were housewives. Greater part $(69.3 \%)$ of study subjects was following Hindu religion, followed by Muslim (21.0\%). Majority $(70.7 \%)$ of study participants belonged to families with socio economic class IV. $82 \%$ mothers were living in a nuclear type of family. $69.7 \%$ mothers had taken antenatal care during pregnancy.

As revealed from table 2, $264(88 \%)$ children were started early breast feeding (within first hour following birth).

$91.9 \%$ women who were in the age group of 26-30 years age group started early breast feeding which was significantly $(\mathrm{p}<0.05)$ highest proportion among all the age groups. None of the mother from age group started early breast feeding in the age group 15-20 years (however the number of subjects in the age groups was insufficient to reveal the true picture).

Highest proportion of subjects $(94.4 \%)$ who started early breast feeding were found to have education up to primary level $(\mathrm{p}<0.05)$ followed by education up to secondary level $(91.7 \%, \mathrm{p}<0.05)$.

All the women who were from higher socio economic class (SE class I and II) started early breast feeding. 
Results showed that $93.8 \%$ of mothers who received antenatal care started early breast feeding compared to $74.7 \%$ who did not receive ante natal care. This difference between two groups was highly significant $(\mathrm{p}<0.001)$.

The number of mothers who gave pre-lacteal feed to their new born was $11(2.75 \%)$. Highest proportion of mothers who provided pre-lacteal feeding to their neonates were from age group 30-35 years $(\mathrm{p}<0.001)$.

Mothers with level of education showed almost similar findings in terms of providing pre-lacteal feeding to their children. Highest proportion $(8.3 \%)$ of women who showed the practice of pre-lacteal feeding belonged to family with SE class III (8.3\%). Those women who did not receive antenatal care demonstrated significantly worse results $(9.9 \%)$ in terms of providing pre-lacteal feed as compared to those who received antenatal care $(1.0 \%)$
Table 3 shows that $281(66 \%)$ mothers out of the sampled population were giving exclusive breast feeding.

The highest proportion $(96.5 \%)$ of mothers who provided exclusive breastfeeding to their infants is from age group 21 to 25 years, while lowest proportion $(66.7 \%)$ was seen from age group 30 to 35 years.

All the mothers who were graduate or above, provided exclusive breast feeding to their infants, while $74.4 \%$ illiterate mothers were providing exclusive breast feeding $(\mathrm{p}<0.001)$.

Most women (98.6\%) from SE Class IV were practicing exclusive breast feeding. About $95 \%$ mothers who taken antenatal cares were exclusively breast feeding their infants. Only 12 (3\%) study population was providing predominant breast feeding. No significant association was found between age of mother and predominant breast feeding practice.

Table 1: Socio demographic profile of study sample.

\begin{tabular}{|c|c|c|c|}
\hline \multicolumn{2}{|l|}{ Characteristics } & Frequency & $\%$ \\
\hline \multirow{2}{*}{ Gender of child } & Male & 167 & 55.7 \\
\hline & Female & 133 & 44.3 \\
\hline \multirow{4}{*}{ Age of mother } & $15-20$ & 1 & 0.3 \\
\hline & $21-25$ & 144 & 48.0 \\
\hline & $26-30$ & 149 & 49.7 \\
\hline & $30-35$ & 6 & 2.0 \\
\hline \multirow{5}{*}{ Education of mother } & Illiterate & 43 & 14.3 \\
\hline & Primary & 197 & 65.7 \\
\hline & Secondary & 36 & 12.0 \\
\hline & Higher Secondary & 19 & 6.3 \\
\hline & Graduate or above & 5 & 1.7 \\
\hline \multirow{4}{*}{ Occupation of mother } & Housewife & 152 & 50.7 \\
\hline & Service & 60 & 20.0 \\
\hline & Labor & 67 & 22.3 \\
\hline & Business & 21 & 7.0 \\
\hline \multirow{4}{*}{ Religion } & Hindu & 208 & 69.3 \\
\hline & Muslim & 63 & 21.0 \\
\hline & Christian & 24 & 8.0 \\
\hline & Other & 5 & 1.7 \\
\hline \multirow{5}{*}{ Socio economic class* } & Class I & 1 & 0.3 \\
\hline & Class II & 12 & 4.0 \\
\hline & Class III & 38 & 12.7 \\
\hline & Class IV & 212 & 70.7 \\
\hline & Class V & 37 & 12.3 \\
\hline \multirow{2}{*}{ Type of family } & Nuclear family & 246 & 82.0 \\
\hline & Joint family & 54 & 18.0 \\
\hline \multirow{2}{*}{ Ante natal care taken } & Yes & 209 & 69.7 \\
\hline & No & 91 & 30.3 \\
\hline
\end{tabular}

\footnotetext{
* By Modified Prasad Classification.
} 
Table 2: Factors affecting early initiation of breast feeding and pre lacteal feeding practices.

\begin{tabular}{|c|c|c|c|c|c|c|c|c|c|}
\hline \multirow[t]{2}{*}{ Characteristics } & \multicolumn{5}{|c|}{ Early initiation of breast feeding ( $n=264$ ) } & \multicolumn{4}{|c|}{ Pre-lacteal feeding among children ( $\mathrm{n=11})$} \\
\hline & & $\mathbf{N}$ & $\%$ & $\begin{array}{l}\text { OR } \\
\text { (LCI-UCI) }\end{array}$ & $\begin{array}{l}\text { P (Fisher's } \\
\text { Test) }\end{array}$ & $\mathbf{N}$ & $\%$ & $\begin{array}{l}\text { OR } \\
\text { (LCI-UCI) }\end{array}$ & $\begin{array}{l}\text { P(Fisher' } \\
\text { s Test) }\end{array}$ \\
\hline \multirow{4}{*}{ Age of mother } & $15-20$ & 0 & 0.0 & NA & NA & 0 & 0.0 & NA & NA \\
\hline & $21-25$ & 123 & 85.4 & $0.62(0.31-1.26)$ & 0.215 & 6 & 4.2 & $1.313(0.391-4.400)$ & 0.763 \\
\hline & $26-30$ & 137 & 91.9 & $2.15(1.04-4.50)$ & 0.0497 & 2 & 1.3 & $0.214(0.045-1.011)$ & 0.06 \\
\hline & $30-35$ & 4 & 66.7 & $0.26(0.05-1.48)$ & 0.154 & 3 & 50.0 & $35.75(6.224-205.350)$ & $<0.001$ \\
\hline \multirow{5}{*}{$\begin{array}{l}\text { Level of } \\
\text { education }\end{array}$} & Illiterate & 24 & 55.8 & $0.09(0.04-0.19)$ & $<0.001$ & 2 & 4.7 & $1.344(0.280-6.447)$ & 0.661 \\
\hline & Primary & 186 & 94.4 & $5.42(2.54-11.55)$ & $<0.001$ & 5 & 2.5 & $0.421(0.125-1.415)$ & 0.196 \\
\hline & Secondary & 33 & 91.7 & $1.57(0.46-5.42)$ & 0.593 & 3 & 8.3 & $2.909(0.734-11.516)$ & 0.133 \\
\hline & $\begin{array}{l}\text { Higher } \\
\text { Secondary }\end{array}$ & 17 & 89.5 & $1.17(0.26-5.29)$ & 1.000 & 1 & 5.3 & $1.506(0.182-12.428)$ & 0.519 \\
\hline & $\begin{array}{l}\text { Graduate } \\
\text { or above }\end{array}$ & 4 & 80.0 & $0.10(0.02-0.37)$ & 0.001 & 0 & 0.0 & NA & NA \\
\hline \multirow{5}{*}{$\begin{array}{l}\text { Socio } \\
\text { economic } \\
\text { class }\end{array}$} & Class I & 1 & 100.0 & $0.42(0.02-10.40)$ & 1.000 & 0 & 0.0 & NA & NA \\
\hline & Class II & 12 & 100.0 & $3.61(0.21-62.39)$ & 0.372 & 1 & 8.3 & $2.818(0.327-24.256)$ & 0.339 \\
\hline & Class III & 35 & 92.1 & $1.68(0.49-5.78)$ & 0.593 & 6 & 15.8 & $9.638(2.781-33.393)$ & $<0.001$ \\
\hline & Class IV & 187 & 88.2 & $1.07(0.50-2.28)$ & 0.847 & 3 & 1.4 & $0.143(0.037-0.554)$ & 0.003 \\
\hline & Class V & 29 & 78.4 & $0.43(0.18-1.03)$ & 0.062 & 1 & 2.7 & $0.702(0.087-5.657)$ & 1.000 \\
\hline \multirow[t]{2}{*}{$\begin{array}{l}\text { Ante natal } \\
\text { care taken }\end{array}$} & Yes & 196 & 93.8 & \multirow[t]{2}{*}{$5.10(2.45-10.63)$} & \multirow[t]{2}{*}{$<0.001$} & 2 & 1.0 & \multirow{2}{*}{$0.088(0.018-0.416)$} & \multirow[t]{2}{*}{$<0.001$} \\
\hline & No & 68 & 74.7 & & & 9 & 9.9 & & \\
\hline
\end{tabular}

Table 3: factors affecting exclusive breastfeeding and predominant breast feeding practices.

\begin{tabular}{|c|c|c|c|c|c|c|c|c|c|}
\hline \multirow[t]{2}{*}{$\begin{array}{l}\text { Characteris } \\
\text { tics }\end{array}$} & \multicolumn{5}{|c|}{ Exclusive Breastfeeding (n=281) } & \multicolumn{4}{|c|}{ Predominant Breast Feeding (n=12) } \\
\hline & & $\mathbf{N}$ & $\%$ & OR (LCI-UCI) & $\begin{array}{l}\text { P (Fisher's } \\
\text { Test) }\end{array}$ & $\mathbf{N}$ & $\%$ & $\begin{array}{l}\text { OR (LCI- } \\
\text { UCI) }\end{array}$ & $\begin{array}{l}\text { P(Fisher's } \\
\text { Test) }\end{array}$ \\
\hline \multirow{4}{*}{$\begin{array}{l}\text { Age of } \\
\text { mother }\end{array}$} & $15-20$ & 1 & 100.0 & NA & NA & 0 & 0.0 & NA & NA \\
\hline & $21-25$ & 139 & 96.5 & $2.74(0.96-7.82)$ & 0.059 & 8 & 5.6 & $2.23(0.66-7.60$ & 0.242 \\
\hline & $26-30$ & 137 & 91.9 & $0.56(0.21-1.45)$ & 0.245 & 3 & 2.0 & $0.32(0.09-1.22$ & 0.138 \\
\hline & $30-35$ & 4 & 66.7 & $0.12(0.02-0.71)$ & 0.049 & 1 & 16.7 & $5.14(0.55-47.8 \varepsilon$ & 8) 0.219 \\
\hline \multirow{5}{*}{$\begin{array}{l}\text { Level of } \\
\text { Education }\end{array}$} & Illiterate & 32 & 74.4 & $0.09(0.03-0.25)$ & $<0.001$ & 4 & 9.3 & $3.19(0.92-11.1$ & 11) 0.076 \\
\hline & Primary & 194 & 98.5 & $11.89(3.38-41.89)$ & $<0.001$ & 7 & 3.6 & $0.72(0.22-2.33$ & 3) 0.553 \\
\hline & Secondary & 34 & 94.4 & $1.17(0.26-5.29)$ & 1 & 0 & 0.0 & NA & NA \\
\hline & Higher & 16 & 84.2 & $0.32(0.08-1.22)$ & 0.109 & 1 & 5.3 & $1.36(0.17-11.1$ & 16) 0.550 \\
\hline & $\begin{array}{l}\text { Graduate or } \\
\text { Above }\end{array}$ & 5 & 100.0 & NA & NA & 0 & 0.0 & NA & NA \\
\hline \multirow{5}{*}{ SE Class } & Class I & 0 & 0.0 & NA & NA & 1 & 100. & NA & NA \\
\hline & Class II & 8 & 66.7 & $0.11(0.03-0.41)$ & 0.004 & 4 & 33.3 & $17.5(4.35-70.3$ & 34) 0.006 \\
\hline & Class III & 36 & 94.7 & $1.25(0.28-5.64)$ & 1 & 2 & 5.3 & $1.40(0.29-6.65$ & 5) 0.653 \\
\hline & Class IV & 209 & 98.6 & $15.48(4.38-54.69)$ & $<0.001$ & 3 & 1.4 & $0.13(0.03-0.48$ & 0.001 \\
\hline & Class V & 28 & 75.7 & $0.12(0.05-0.33)$ & $<0.001$ & 2 & 5.4 & $1.45(0.30-6.87)$ & 0.65 \\
\hline \multirow{2}{*}{$\begin{array}{l}\text { Ante Natal } \\
\text { Care Taken }\end{array}$} & Yes & 199 & 95.2 & \multirow{2}{*}{$2.18(0.86-5.57)$} & \multirow{2}{*}{0.12} & 8 & 3.8 & \multirow{2}{*}{$0.87(0.25-2.95)$} & \multirow{2}{*}{0.759} \\
\hline & No & 82 & 90.1 & & & 4 & 4.4 & & \\
\hline
\end{tabular}

Majority of the illiterate mothers $(9.3 \%)$ were practicing predominant breast feeding. All the mothers from SE Class I were predominantly breast feeding. However the no. of mothers in SE class I is inadequate to reach any conclusion. Almost $4 \%$ mothers who had taken antenatal care, were practicing predominant breast feeding which were non-significantly lower number than those who had not taken antenatal care. 


\section{DISCUSSION}

The present study shows that $66 \%$ mothers started breast feeding within 1 hour following delivery. The data from National Family Health Survey-3 Shows that $30.3 \%$ mother's started early breast feeding in urban area. ${ }^{6}$ This comparison shows that there has been major improvement in the mentioned indicator since 2006. Another study conducted at New Delhi by Khan AM et al shows proportion of mentioned indicator as $37.2 \%{ }^{7} \mathrm{~A}$ study conducted by Das $\mathrm{N}$ et al in rural area of India showed that $34.2 \%$ mothers started early breast feeding. ${ }^{8}$ It was seen that highest proportion of mothers who initiated breast feeding within one hour were from age group 26 to 30 years. This result is comparable to the previous study conducted in Nigeria. ${ }^{9}$ The current study could find significant association between mothers who had at least primary level of education and early initiation of breast feeding. Early initiation of breast feeding was found significantly lower among illiterate mothers. It was also observed that three antenatal visits had significant effect on the practice of starting breast feeding within 1 hour following birth. These findings are again supported by the study conducted in Nigeria. ${ }^{9}$

Majority of mothers who gave pre lacteal feeding to their child were of less than 25 years of age. Similar finding was also seen in the study conducted by Roy MP et al. ${ }^{10}$ There was no effect of mother's education on practice of providing pre lacteal feeding. Again this finding can be consolidated by findings of previous study conducted by Kishor $\mathrm{S}$ et al. ${ }^{11}$ Previous survey has found that practice of pre lacteal feeding is seen in lower socioeconomic classes. ${ }^{12}$ However current study showed contradictory results showing prevalence of pre lacteal feeding practice was low amongst poor sections of the study population. The frequency of antenatal visits can influence the practice of prelacteal feeding. Our study revealed that mothers, who had received minimum three antenatal visits, did not significantly indulge in the practice of prelacteal feeding. Previous studies have depicted that advices by health worker for not providing prelacteal feeding has substantial effect on mother's behaviour regarding the same. ${ }^{13}$

The present study revealed that there was no effect of age of mother on practice of exclusive breast feeding. A previous study conducted in Ethiopia was able to establish significant association between mother's age (>=40 years) and practice of exclusive breastfeeding. ${ }^{14}$ Current study could surprisingly reveal that mothers who were illiterate and educated up to primary level were significantly following practice of exclusive breast feeding. Mothers belonging to SEC IV and V were also exclusively breast feeding their children. The findings of our study are in sharp contrast with the results of the study conducted in south Gujarat in India as far as education of mother is concerned, while similar findings were seen in context of SEC.
Our study could not find significant association between level of education, age of mother and no. of ANC visits with practice of predominant breastfeeding, while significant association was seen between SEC IV and practice of predominant breast feeding. The similar study conducted in Nigeria could establish significant association between education of mother, SEC and no. of ANC visits and practice of predominant breast feeding. ${ }^{9}$

\section{CONCLUSION}

The current study provides a perspective regarding prevalent IYCF practices in urban area of India. The study shows that the IYCF indicators are not up to the mark and improvement in the IYCF indicators is the need of the hour to reduce Infant Mortality Rate (IMR) in India. The socio-demographic characteristics like education of mother, maturity of nursing mother, socio economic class of mother and antenatal care received by mother also play major role in determining the IYCF practices. It is advisable to educate mothers regarding IYCF guidelines during antenatal care.

Funding: No funding sources

Conflict of interest: None declared

Ethical approval: The study was approved by the Institutional Ethics Committee

\section{REFERENCES}

1. UNICEF. Commiting to child survival: A Promise Reviewed. Progress Report. 2014;12-13.

2. India, Office of the Registrar General and Census Commissioner of. Census India. [Online] [Cited: 05 07, 2015.] http://www.censusindia.gov.in/ vital_statistics/SRS_Reports_2013.html.

3. Ministry of HR Development, Dept. of Women and Child Development, GOI. National Guidelines on Infants and Young Child Feeding Practices. 2004;7.

4. Pelletier DL, Frongillo EA Jr, Schroeder DJ, Habicht JP. The effects of malnutrition on child mortality in developing countries. Bull Word Health Organization. 1995;73:443-8.

5. (WHO), World Health Organization. The optimal duration of exclusive breast-feeding: report of an expert consultation. Geneva : s.n. 2001.

6. International Institute for Population Sciences. www.rchiips.org. [Online] [Cited: June 10, 2015.] http://www.rchiips.org/ nfhs/ pdf/ Gujarat.pdf.

7. Khan AM, Kayina P, Agrawal P, Gupta A, Kannan AT. A Study on infant and young child feeding practices among mothers attending an Urban Health Center in East Delhi. 4, New Delhi. Indian Journal of Public Health. 2012;56:302.

8. Das N, Chattopadhyay D, Chakraborty S, Dasgupta A. Infant and young child feeding perceptions and practices among mothers in a rural area of West Bengal, India. Ann Med Health Sci Res. 2013; 3(3):370-5. 
9. Ogbo FA, Agho KE, Andrew. Determinants of suboptimal breastfeeding practices in Nigeria: evidence from the 2008 demographic and health survey. BMC Public Health. 2015;15:259.

10. Roy MP, Mohan U, Singh SK, Singh VK, Srivastava AK. Determinants of Prelacteal Feeding in Rural Northern India. Int $\mathrm{J}$ Prev Med. 2014;5:658-63.

11. Kishore S, Garg BS Practice of prelacteal feeding in a rural community. Indian J Public Health. 1999;43:144-7.

12. Mumbai: IIPS: National Family Health Survey (NFHS-3), India. International Institute for Population Sciences (IIPS) and Macro International. Uttar Pradesh : s.n., 2008.
13. Akuse RM, Obinya EA. Why health care workers give prelacteal feeds. Eur J Clin Nutr. 2002;56:72934.

14. Teka B, Assefa H, corresponding author and Kiday Haileslassie Prevalence and determinant factors of exclusive breastfeeding practices among mothers in Enderta woreda, Tigray, North Ethiopia: a crosssectional study. Int Breastfeed J. 2015;10.

Cite this article as: Rana BM, Chandwani $\mathrm{H}$, Sonaliya KN, Prajapati A. A descriptive study to assess factors affecting core indicators of infant and young child feeding practices in urban area of Gujarat State, India. Int J Community Med Public Health 2016;3:1101-6. 